\title{
The Unexpected Revolution
}

Social forges in the hungarian uprising. Paul Kecskemeti. An analysis of the impact of totalitarianism upon different social groups in Hungary-Communist party functionaries and intellectuals, non-party intelligentsia, workers, peasants, students-yields many reasons why the Hungarian revolt succeeded where uprisings in other satellite countries failed.

$\$ 4.75$

\section{Falange}

A History of SPANish fascism. Stanley G. Payne. The first detailed study of Spain's fascist party, the book provides much new information on the inner workings of the Franco regime. Besides illuminating many particular aspects of Spanish political life, the book offers valuable observations on the nature of fascism in general.

$\$ 6.50$

\section{The Levellers and the English Revolution.}

$H$. N. Brailsford. The significance of the Levellers in English history has never before been so convincingly demonstrated as in this brilliant full-scale history of the movement. The book, to which Brailsford dedicated the last ten years of his life, has been edited and prepared for publication by Christopher Hill.

\section{The Story of Fabian Socialism}

Margaret Cole. Here is a complete account by a firsthand witness of the turbulent and colorful history of the Fabian Society, the author being the wife of the late G. D. H. Cole and herself one of the Society's leaders. Indispensable background material on the genesis of the Welfare Society, it provides a chronicle of various related movements as well.

$\$ 6.50$

Order from your bookstore, please

\section{STANFORD UNIVERSITY PRESS}




\section{The Russian Provisional Government, 1917}

Documents. Selected and Edited by Robert Paul Browder and Alexander $F$. Kerensky. Drawing upon the collections of the Hoover Institution on War, Revolution and Peace, and aided by the recollections of the former Prime Minister of the Provisional Government, these three volumes present a complete picture of the period from March to November 1917 in Russia. Official documents, pamphlets, memoirs, correspondence, manuscripts, and contemporary press reports are translated and annotated. A publication of the Hoover Institution.

Three Volumes, $\$ 30.00$

\section{The French in Germany, 1945-1949}

F. Roy Willis. The first history in any language of the French zone of occupation, this study gives new material on internal political and economic developments in Germany and France, and illuminates the complicated attempts of the Allied powers to solve the general problem of postwar Germany.

About $\$ 6.00$

\section{Neo-Freudian Social Philosophy}

Martin Birnbach. The implications of psychoanalytic theory for contemporary social and political problems are outlined in this analysis of the writings of Franz Alexander, Erich Fromm, Karen Horney, Abram Kardiner, and Harry Stack Sullivan. There is in addition an exposition of Harold D. Lasswell's work on the application of the psychoanalytic viewpoint to politics.

About $\$ 6.50$

Order from your bookstore, please

\section{STANFORD UNIVERSITY PRESS}




\section{INTERNATIONAL STUDIES}

\section{Journal of the Indian School of International Studies}

International Studies is published quarterly by the Indian School of International Studies, New Delhi and contains articles in the fields of modern International Politics, Economics, and $L a w$ as well as on political, economic and social developments in Asia or other areas.

\begin{tabular}{lll}
\hline 3rd year & Vol. III & No. 1 (July 1961) \\
\hline
\end{tabular}

\section{Contents}

Arnold and Veronica Toynbee: Problems of research in International Relations

M. S. Agwani: The Ba'th: A study in Contemporary Arab Politics

Jahar Ray: The European Free Trade Association and Its Impact on India's Trade

Gargi Dutr: The Rural People's Communes of China

Nagendra Singh and M. K. Nawaz: The Contemporary Practice of India in the Field of International Law (1960)

Notes and Memoranda Survey of Source Material

The Price of International Studies is Rs. 6.00 a number (\$1.80) or Rs. $22.00(\$ 6.60)$ per annum. Copies may be obtained from Asia Publishing House, Contractor Building, Nicol Road, Ballard Estate, Bombay 1, to which address all correspondence should be addressed.

\section{PARLIAMENTARY AFFAIRS}

\section{The Quarterly Journal of the Hansard Society for Parliamentary Government}

\section{The current issue includes articles on:}

Parliamentary Developments, March-May 1961

The Old House of Commons and its Members
(c. 1783-1832) - III
A. Aspinall

The French Referendum, 1961

Philip M. Williams

The Power of the Contemporary Presidency

Robert S. Hirschfield

The Implications of the Potential Strength of the

Liberal Party for the Future of British Politics Jorgen Rasmussen

With a comment by Mark Bonham Carter

Single Copies 7s. 6d., $\$ 1.25$

Annual Subscription 30s., $\$ 4.50$

THE HANSARD SOCIETY FOR PARLIAMENTARY GOVERNMENT 79/80 Petty France, London, S.W.I 


\section{SALE - Back Numbers of The Review of Politics}

\section{Any five issues for a total of $\$ 3.00$. Additional issues at $\$ .50$ each. This offer expires Dec. 31, 1961.}

Vol. 18, No. 3, July, 1956

Hans Kohn: Some Remporions on ColoNIALISM.

Robert C. Tucker: The Cunning of Renson n Hzozl and Marx.

Peter F. Drucker: Organized Religion and the American Crezd.

Elizabeth Valkenier: Trre Catholic Crurch in Communist Pozand, 1945-1955.

Thomas N. Brown: The Orsorns and GraraCter of IrISH-AMgrican NationalisM.

Vol. 18, No. 4, October, 1956

Hannah Arendt: Authority in the TweNtreth Century.

Kenneth W. Thompson: TOYNBEs AND Woru Politics: Democracy and Foreion Policy.

Melvin Richter: T. H. Green AND His AUdiznce: Lrberalisa as a Surrogate Fatth.

L. Labedz: RUssta APTER KHRUSHCHEV.

Francis Dvornik: The Mediaeval Culturn. Heritage of the Mid-European Area.

Vol. 19, No. 1, January, 1957

Stephen D. Kertesz: Reflections oN Soviet aNd American Negotiating Behavior.

G. de Bertier de Sauvigny: Population Movements and Political Changes in Ninetezenth Centugy France.

Christopher Dawson: The BIRTH of DEMocrucY.

Gilbert A. Cahill: Irish Catholicism and ENGLish TORYISM.

Samuel M. Osgood: A Pretender's Congept OF the French Monarchy.

Michael P. Fogarty: Britain aND Europe Since 1945.

Vol. 19, No. 2, April, 1957

Josef Pieper: KNowledge and Frerdom.

Hans Kohn: Nationalism in THB Low Countries.

Henty S. Albinski: The Concept of Partnership in the Central. African Federation.

Leo R. Ward, C.S.C.: JoHN DEWEY IN SEARCK OP HIMselp.

W. F. Murphy: The Polimical Thovoh of Gerald Winstanley.

Vol. 19, No. 3, July, 1957

Gustave Weigel, S.J.; Ambrican Catholio Intellectualism - A TheologinN's RETLECTIONS.

Edward Taborsky: The Revolt of the CoMMUNI8T INTRLLECTUALS.
J. W. N. Watkins: Tres Postrumous Carzes of Thomas HoBbes.

Irwin Abrams: Treg Emergence op THE INTERNATIONAL LAW Soctrtirs.

Vol. 19, No. 4, October, 1957

M. A. Frtzsmons: The Sugz Caris and the Containment Policy.

William H. Lewis: IsLam: A Rusno Troe is Tropical Aprica.

Sydney D. Bailey: "Pozice Socinzisu" ns Tsarist Russia

Dirk Jellema: AвrahaM KuYper's Atraok on LiBernulism.

Andreas Dorpalen: Hrtue - Tweuve YeArs Afrzk.

Vol. 20, No. 1, January, 1958

Louis de Raeymaeker: What St. Thomas Mzans Today.

Bruce Mazlich: The Conservattve RevolvTION OF EDMUND BURKe.

Morton J. Frisch: John Marshatr's PHzlosophy of Constitutional RepublicanISM.

Joseph N. Moody: The Dechristinanization of the French Working Class.

Justus M. van der Kroef: Thz Trials of Indonesian Democracy.

Ulrich S. Allers: Rousszau's Szcono DisCOURSE.

Vol. 20, No. 2, April, 1958

Guy B. Johnson: Fregoom, EqualtTY, aND Szgregation.

Fauzi M. Najjar: IszaM and Modern DEMOCracy.

Fred D. Schneider: The Commonwentri in Transition.

Charles M. Hardin: Americnn Agriculture.

Zygmunt J. Gasiorowski: BENES AND LoCARNo: Some UnPUBLISHEd DOCUMENTS.

Thomas Molnar: The Political Thoveht of Bernanos.

Vol. 20, No. 3, July, 1958

Paul H. Nitze: The Role of the Lenrege Man IN Government.

Arthur E. Adams: Bolshevik AdministzaTION IN THE UKRAINE-1918.

D. Novak: The Plack of Anarchism in the History of Political Thovght.

Edward J. Goodman: "Spanish Nationalism in the Strugels Against NapolzoN.

Arthur L. Smith, Jr.: Generac von Sezckx AND THE WeIMAR REPUBLIC.

John Ely Burchard: Tre Mraning of ArchITECTURE.

Address orders and payment to THE REVIEW OF POLITICS, Box 4, Notre Dame, Indiana. 
A good way to keep informed about European and World Affairs is to read regularly

\section{E U R O P A - A R C H I V}

The Journal of the German Council on Foreign Relations

Edited by Wilhelm Cornides

Articles in recent issues:

Wruseu Corvios: Berlin-und was dann?

UWz Krrzwosa: Für und wider den Beitritt Grossbritanniens zur EWG

Hrlmut Alzarot: Praktische Möglichkeiten der Entwicklungshilfe in Afrika

Nonserat KoHLHasz: Zum politischen Charakter der Europäischen Wirtschaftsgemeinschaft

Fritz Steppat: Der Weg der algerischen Nation

Gotrrazn-Karl. KINDrRmanN: Paradoxien der inneren und auswärtigen Politik Japans

EurofA-Archiv, now in its 16 th year of publication, contains articles and documents on international relations and a current chronology of world events as well as review articles of recent publications.

Annual subscription (24 issues) DM 56, plus postage Specimen copies on request

DEUTSCHE GESELLSCHAFT FUR AUSWÄRTIGE POLITIK

Abt. Europa-Archiv, Frankfurt am Main, Gr. Eschenheimer Str. 16/18

\section{INTERNATIONAL ORGANIZATION}

Contains in Volume XV, Number 3, Summer 1961

1. Articles

De Gaulle's France and NATO:

An Interpretation Edgar S. Furniss, Jr.

International Integration: The European and the Universal Process Ernst B. Haas

Trends in United Nations Administration....................Walter Sharp

Neutral Austria in the United Nations......................Karl Zemanek

II. Comprehensive Summaries

Recent activities of United Nations organs and of the specialized agencies

Recent activities of major regi nal and functional organizations

III. Selected Bibliography

Pertinent books and articles in United States and foreign periodicals

$\$ 5.00$ a year

$\$ 1.50$ a copy
WORLD PEACE FOUNDATION $40 \mathrm{Mt}$. Vernon Street

Boston 8, Mass., U.S.A. student rate

$\$ 3.50$ a year 